\title{
М.Б. Горобейко
}

\section{ВИЗНАЧЕННЯ ЕФЕКТИВНОСТІ ПОВТОРНОГО КУРСУ МЕДИКАМЕНТОЗНОЇ ТЕРАПІЇ ХВОРИХ НА ЦУКРОВИЙ ДІАБЕТ IЗ НЕКРИТИЧНОЮ ПЕРИФЕРИЧНОЮ АНГІОПАТІЕЮ}

\author{
Украӥнський науково-практичний иеентр ендокринної хірургії, \\ трансплантачії ендокринних органів і тканин МОЗ України, Київ
}

\section{ВСтуп}

За численними літературними даними, тривалість лікування хворих із синдромом діабетичної стопи (СДС) може досягати 12-25 тижнів і включати 2-5 курсів на рік [1-4]. Окремо слід зазначити, що лікування ускладнень цукрового діабету, надто периферичної ангіопатії, вимагає багатократного призначення препаратів, які впливають на реологію крові, прохідність судин тощо. Тому необхідність вивчення ефективності повторного призначення препарату обумовлено саме практичними потребами.

Принципи комплексної терапії СДС визначаються його етіологією та патогенезом. Головною умовою профілактики та успішного лікування ускладнень $є$ компенсація гіперглікемії. Поруч із цим, сучасною тенденцією $є$ включення до комплексної терапії цукрового діабету не лише ефективних цукрознижувальних засобів, але й препаратів, що зменшують оксидативний стрес, інсулінорезистентність і гіпоксію, поліпшують реологічні властивості крові, мають фібринолітичну активність, забезпечують організм необхідними мікроелементами, амінокислотами, гліколіпідами $[6,8,9,11]$. До таких засобів належить актовегін [10]. Актовегін впливає на процеси внутрішньоклітинного метаболізму, під його дією поліпшується транспорт глюкози та поглинання тканинами кисню, що приводить до активації процесів аеробного окислення та збільшення енергетичного потенціалу клітини. Актовегін сприяє відновленню кровопостачання у зоні ішемії, що пов'язано з прискоренням васкуляризації та розвитком колатерального кровообігу, зменшенням вторинного негативного впливу кисневої недостатності на стінку судин, надто на ендотелій. В умовах гіпоксії тканин цей препарат сприяє відновленню капілярної сітки за рахунок новоутворених судин [7]. Після введення актовегіну активується місцевий фібриноліз, підвищуються лужні резерви крові, внаслідок чого зменшується ії щільність. Крім того, актовегін стимулює еритропоез, транспортну функцію еритроцитів, сприяє збільшенню терміну їх життя.

\section{МАТЕРІАЛ I МЕТОДИ}

До дослідження було залучено 49 хворих на цукровий діабет 2-го типу. Базове лікування в усіх складалося з нормалізації рівня глюкози у крові - 29 хворих отримували інсулін відповідно до призначень ендокринологів, решта - пероральні цуркознижувальні препарати. Дослідна група (38 пацієнтів) як патогенетичну терапію повторно отримувала актовегін (через 8-13 міс. після першого призначення), група контролю (КГ) - 11 пацієнтів - базове лікування без застосування актовегіну. Усі пацієнти були стратифіковані відповідно до класифікації PEDIS (P - перфузія, E - площа виразки, D - глибина виразки, I - рівень інфікування, S - чутливість) [5], тобто за рівнем парціального тиску кисню у тканинах нижніх кінцівок. Пацієнти групи контролю не мали ознак критичної ішемії: парціальний тиск кисню у тканинах нижньої кінцівки $\left(\mathrm{TcPO}_{2}\right)$ у них був у межах 28-39 мм рт. ст., середній показник склав 34,2 33,7 мм рт. ст. У першій дослідній групі (1ДГ) було 38 пацієнтів 3 ознаками ішемії, проте без ії критичних показників, у яких вивчали ефективність актовегіну після первинного призначення. $\mathrm{TcPO}_{2}$ у них був у межах 27-42 мм рт. ст. (35,21 7,1 мм рт. ст.), середній вік склав 53,8ะ7,49 року. Середня тривалість після виявлення цукрового діабету складала у контрольній групі 6,89 3,44 року, у $1 Д Г-6,45 \pm 3,57$ року; середній рівень глікова-

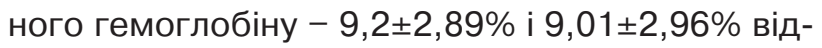
повідно. Парціальний тиск кисню у тканинах нижніх кінцівок визначали на 8-у, 20-у, 45-у добу лікування та через 10 і 20 днів після повторного введення. Другу дослідну групу (2ДГ) склали ті ж самі хворі, яким було призначено повторний 
курс актовегіну через 8-13 міс. На час початку другого курсу $\mathrm{TcPO}_{2}$ у них був у межах 2448 мм рт. ст. (33,33 $\pm 9,3$ мм рт. ст.), рівень глі-

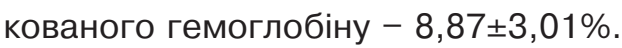

Розподіл пацієнтів у групах за класифікацією PEDIS наведено у таблиці 1. Слід зазначити, що до цієї таблиці включено лише 26 пацієнтів, у яких через 8-13 місяців ще мав місце виразковий дефект, адже дану класифікацію застосовують лише для хворих із наявністю виразкового дефекту. Розмір виразки визначали за цифровою методикою за запатентованою програмою, з використанням цифрової фотокамери. У нашому варіанті Е1 - розмір виразки до 2 см, Е2 - до 4 см, Е3 - більше за 4 см.

Слід зазначити, що до дослідження не включали пацієнтів з ознаками генералізації інфекційного процесу. Практично в усіх хворих спостерігалися ті або інші ознаки нейропатії. Дослідні групи були порівнянними з контрольною як за віком пацієнтів, рівнем компенсації цукрового діабету, так і за тривалістю і стадійністю процесу.

Черезшкірне визначення парціального тиску кисню в тканинах нижньої кінцівки проводили на апараті ТСМ 400 виробництва датської фірми "Радіометр" за стандартними методиками.

Пацієнти як контрольної, так і дослідних груп отримували низькомолекулярні гепарини. 9 пацієнтів із КГ, 25 пацієнтів із ДГ отримували антибіотики через наявність інфекційного процесу у виразці. Топічне (місцеве) лікування проводили усім хворим, і полягало воно в етапній некректомії, дренуванні рани та застосуванні протимікробних засобів (не місцева антибіотикотерапія).

Хворим із Дг призначали актовегін за схемою: внутрішньовенно крапельно 2000 мг 1 раз на добу протягом 12 днів із наступним пероральним прийманням 200 мг (1 таблетка) 3 рази на добу терміном до 45 днів.

\section{РЕЗУЛЬТАТИ ТА ОБГОВОРЕННЯ}

Результати лікування оцінювали шляхом визначення динаміки парціального тиску кисню у тканинах нижніх кінцівок. Крім цього, спостерігали динаміку загоєння виразки та лікування інфекційного процесу та визначали можливу нестерпність препарату.

Важливим є той факт, що на момент повторного введення актовегіну у 16 пацієнтів були відсутні виразки. Проте ця цифра вимагає пояснення - після першого курсу лікування актовегіном ми спостерігали загоєння виразки у 19 пацієнтів $(50,0 \%)$, ще у $7(18,42 \%)$ відбувалася активна епітелізація. Отже, практичне загоєння відзначено у 68,42\% випадків. Перед початком повторного курсу у 6 із 7 хворих 3 активною епітелізацією на кінець першого курсу лікування виразка цілком загоїлася. 319 хворих, у яких після першого курсу спостерігалось загоєння, у чотирьох виникли виразки на "старому" місці, у 3 - нові виразки, у 2 - на іншій кінцівці. У 10 хворих із цієї когорти виразок не спостерігалось.

У групі контролю початковий рівень $\mathrm{TcPO}_{2}$

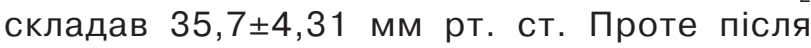
призначення патогенетичного лікування вже че-

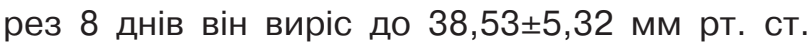
Через 20 днів після початку лікування середнє

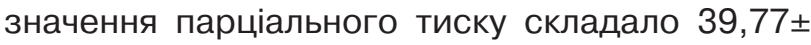
$\pm 8,22$ мм рт. ст. У цей проміжок часу практично в усіх хворих було ліквідовано гнійне запалення виразки і відбувалося поступове загоєння виразки. Через 45 днів $\mathrm{TcPO}_{2}$ у хворих складав 38,36 7,43 мм рт. ст., через 3 місяці він зни-

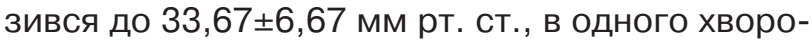
го з'явився новий виразковий дефект, в одного пацієнта зафіксовано загоєння, у 2 - активну епітелізацію, ще у 2 хворих попри суб'єктивне поліпшення виразки "застигли".

У першій дослідній групі (після першого курсу лікування) показники ТсРО 2 змінювалися найбільш однорідно: після 8 днів лікування рівень

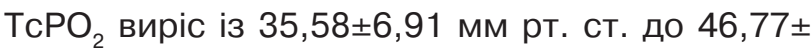
$\pm 5,58$ мм рт. ст. Середні показники через 20 і

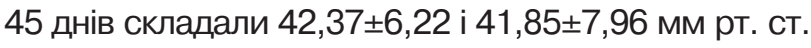
відповідно (на 45-й день лікування було обстежено 14 пацієнтів). В усіх хворих спостерігався

Розподіл пацієнтів за класифікацією PEDIS (n)

Таблиця 1

\begin{tabular}{l|l|l|l|l|l|l|l|l|l|l|l}
\hline Група & E1 & E2 & E3 & D1 & D2 & D3 & I1 & I2 & I3 & S1 & S2 \\
\hline КГ & 3 & 6 & 2 & 2 & 7 & 2 & 2 & 7 & 2 & 3 & 8 \\
1 ГД & 7 & 19 & 13 & 11 & 24 & 4 & 6 & 26 & 7 & 5 & 34 \\
2 ГД & 8 & 10 & 5 & 15 & 4 & 3 & 12 & 9 & 2 & 1 & 22 \\
\hline
\end{tabular}


позитивний ефект лікування - відзначено стійку динаміку загоєння виразок із нормалізацією загального стану кінцівки: зникнення набряку, нормалізація кольору та вологості, відчуття потепління тощо. На 45-й день у 16 хворих виразки загоїлись, у решти - активно епітелізувалися. Через 3 місяці після початку лікування середній

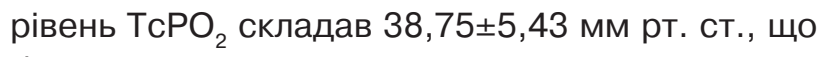
було порівнянним із показником перед початком лікування, проте цілковите загоєння виразки відбулося у 19 випадках, у решти 7 - активна епітелізація. Жодних нових виразок на нижніх кінцівках у хворих не було зафіксовано. Через 6 місяців середній рівень ТсРО 2 складав $34,36 \pm 7,21$ мм рт. ст. В одного хворого розвинулася повторна виразка на "старому" місці, в одного - поверхневий дефект на контрлатеральній стопі, якому запобігли перетворитися на виразку.

У другій дослідній групі (після другого курсу лікування) динаміка показників $\mathrm{TcPO}_{2}$ була аналогічною змінам після першого курсу препарату. Тобто показники $\mathrm{TcPO}_{2}$ після 8 днів лікуван-

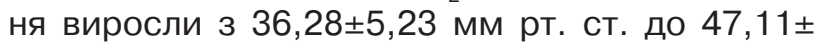
$\pm 6,21$ мм рт. ст. Середні показники через 20 і

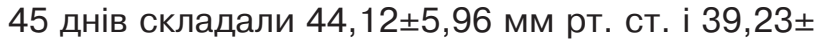
$\pm 8,13$ мм рт. ст. відповідно. Жодних нових виразок у хворих не виникло. Через 3 місяці після початку повторного лікування середній рівень

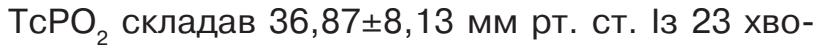
рих із виразками загоєння на 45-й день зафіксовано у 8 (34,78\%), активну епітелізацію - у 6 $(26,09 \%)$ хворих. Отже, стійке загоєння виразки та/або активну епітелізацію після першого курсу лікування актовегіном зафіксовано у 26 $(68,42 \%)$ пацієнтів, після другого курсу - ще у $14(60,87 \%)$.

Отримані результати свідчать про необхідність добору схеми лікування пацієнтів із синдромом діабетичної стопи відповідно до його стадії. Попри незначне на перший погляд зростання парціального тиску кисню у тканинах нижньої кінцівки, спостерігалося суттєве суб'єктивне поліпшення стану та позитивний ефект у вигляді помірно швидкого загоєння виразки. Означені зміни є результатом як поліпшення засвоєння кисню тканинами нижніх кінцівок, так і впливу актовегіну на нейропатію. Це проявлялося відновленням кровопостачання у зоні ішемії, що пов'язано з прискоренням васкуляризації та розвитком колатерального кровообігу, зменшенням вторинної негативної дії кисневої недостатності на стінку судин, надто на ендотелій. В умовах гіпоксії тканин актовегін, можливо, сприяє відновленню капілярної сітки за рахунок стимуляції новоутворення судин. Як вже зазначалося, після введення препарату активується місцевий фібриноліз, підвищуються лужні резерви крові, внаслідок чого зменшується її щільність. Із цим фактом, мабуть, пов'язано пролонгований ефект щодо загоєння виразок. Незважаючи на відсутність вірогідної різниці у парціальному тиску через 6 міс., спостерігається ефективне загоєння ран і виражене, вірогідне зменшення частоти рецидивів виразкових процесів.

Жодних проявів гіперчутливості до препарату серед пацієнтів не було зафіксовано.

\section{ВИСНОВКИ}

1. Лікування актовегіном показало свою ефективність у хворих на синдром діабетичної стопи із некритичною ішемією нижніх кінцівок: вірогідно збільшився парціальний тиск кисню у тканинах нижніх кінцівок як після першого, так і

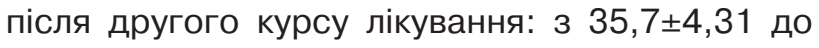
$39,77 \pm 8,22$ мм рт. ст. в групі контролю проти 3

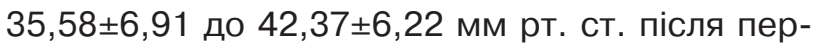

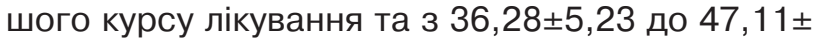
$\pm 6,21$ мм рт. ст. після другого курсу, що, у свою чергу, привело до швидшого загоєння виразок порівняно з групою контролю.

2. Повторний курс актовегіну значно збільшив кількість загоєних виразок у пацієнтів: якщо після першого курсу стійке загоєння спостерігалось у 19 (48,7\%) хворих, то після другого курсу виразки ще загоїлись у 8 хворих, а активна епітелізація спостерігалась у 6 хворих, тобто 27 (69,2\%) хворих були вилікувані від виразки, а у $15,4 \%$ хворих відбувалось активне загоєння, тобто ефект повторного курсу стосовно загоєння склав $84,6 \%$.

3. Навіть після зменшення рівня парціального тиску кисню у тканинах у групі, де застосовувався актовегін, зберігався його позитивний ефект щодо загоєння рани із меншою кількістю рецидивів.

\section{ЛІТЕРАТУРА}

1. Saint Vincent Declaration: A meeting organized by WHO and IDF in Europe // Saint Vicent (Italy), 10-12 October 1989.

2. Практичні рекомендації з лікування та профілактики синдрому діабетичної стопи - підготовле- 
но Міжнародною робочою групою з проблеми діабетичної стопи. - Київ. - 2004. - 16 с.

3. Міжнародна угода з проблеми діабетичної стопи - Київ. - 2004. - 96 с.

4. Consensus Development Conference on Diabetic Foot Wound Care - American Diabetes Association // Diabetes Care. - 1999. - Vol. 22, №8. P. 1354-1360.

5. Горобейко М.Б., Гирявенко О.Я. Класифікація діабетичної стопи, затверджена Міжнародною робочою групою з діабетичної стопи IDF та ВООЗ // Клінічна ендокринологія та ендокринна хірургія. - 2004. - №1(6). - С. 83-87.

6. Ефимов А., Болгарская С. Синдром диабетической стопы. Эпидемиология, патогенез, клиника, диагностика, лечение трофических поражений нижних конечностей у больных сахарным диабетом // Ліки України. - 2005. - №5. C. 45-52.

7. Котов С.В., Калинин А.Л., Рудакова И.Г. Диабетическая нейропатия. - М. - 2000. - 39 с.

8. Goodman G.R., Tersigni S., Ke Li, Lawrence P.F. Trombolytic therapy in an isolated limb // Annals of Vascular Surgery. - 1993. - Vol. 7. - P. 512-520.

9. Bohme $H$. Die konservative therapie der chronischen peripheren arteriellen verschlusskrankheit / / Chirurgische Gastroenterologie. - 1992. Vol. 8 (supl 1). - P. 76-80.

10. Компендиум 2003 - лекарственные препараты / Под ред. В.Н. Коваленко, А.П. Викторова. К.: Морион, 2003. - 1388 с.

11. Diagnostik und Therapie des diabetischen Fusses / M. Weck. - Kreischa, 2002. - 67 p.

\section{РЕЗЮМЕ}

Определение эффективности повторного курса медикаментозной терапии больных сахарным диабетом с некритической периферической ангиопатией

\section{М.Б. Горобейко}

В работе изучали эффективность использования актовегина при периферической ангиопатии разной степени у больных сахарным диабетом. Оценку проводили согласно с принципами доказательной медицины, с использованием стратификационной классификации синдрома диабетической стопы (СДС) PEDIS. Изучали уровни $\mathrm{TcPO}_{2}$ у больных с критической, некритической ишемией и в контрольной группе, а также динамику заживления язв на нижних конечностях у пациентов до начала лечения, через 10, 45 дней и через 3 и 6 месяцев, а также после повторного курса лечения. Препарат вводили в/в капельно 2000 мг 1 раз в день на протяжении 12 дней, затем таблетировано 600 мг в сутки до 45 дней. В исследование включены 39 пациентов, которым проведено 2 курса лечения, и группа контроля - 11 па- циентов. Лечение актовегином показало свою эффективность у пациентов с СДС и некритической ишемией нижних конечностей: достоверно увеличилось $\mathrm{TcPO}_{2}$ в тканях нижних конечностей как после первого, так и после повторного курса, что, в свою очередь, привело к более быстрому заживлению язв по сравнению с группой контроля. Повторный курс лечения актовегином значительно увеличил количество заживших язв: после 1-го курса стойкое заживление произошло в 48,7\% случаев, после второго курса дополнительно зажили язвы еще у 8 пациентов, а активная эпителизация наблюдалась у 6 пациентов, т.е. эффект повторного курса по отношению к заживлению составил 84,6\%. Даже после уменьшения $\mathrm{TcPO}_{2}$ в тканях в группе актовегина сохранялся его положительный эффект по отношению к заживлению раны и уменьшению количества рецидивов. Показано достоверное повышение $\mathrm{TcPO}_{2} \mathrm{y}$ пациентов, получавших актовегин, в группе некритической ишемии уже с 10-х суток от начала лечения с сохранением достоверного эффекта до 3 мес. Доказан пролонгированный эффект (до 6 мес.) в заживлении ран. Установлена эффективность актовегина в комбинированном лечении пациентов с критической ишемией нижней конечности.

Ключевые слова: синдром диабетической стопы, ишемия, лечение, актовегин.

\section{SUMMARY}

The efficiency of a repeated course of drug therapy in diabetic patients with non-critical peripheral angiopathy

\section{B. Gorobeiko}

The efficiency of Actovegin in cases of different stages of peripheral angiopathy in patients with diabetes mellitus on principles of evidence-based medicine using PEDIS classification was estimated. Levels of $\mathrm{TCPO}_{2}$ and speed of healing among patients with critical, non-crtitical ischemia and control groups were estimated before treatment, after 10, 45 days, 3 and 6 months and after secondary course of treatment (2nd course after 8-13 months after the 1st course). Actovegin prescribed intravenously $2000 \mathrm{mg} /$ day during 12 days, than orally $600 \mathrm{mg}$ daily up to 45 days. It was involved 39 patients who received 2 courses of treatment and control group 11 patients with traditional combine treatment of SDF. In control group $\mathrm{TcPO}_{2}$ increased from $35,7 \pm 4,31$ to $39,77 \pm 8,22 \mathrm{mmHg}$ compare with dynamic from $35,58 \pm 6,91$ to $42,37 \pm 6,22 \mathrm{mmHg}$ after 1 st course of treatment and from $36,28 \pm 5,23$ to $47,11 \pm$ $\pm 6,21 \mathrm{mmHg}$ after the 2 nd course of treatment. This improvement leads to healing 19 wounds after the 1st course and 8 wounds and active epitalization in 8 patients additionally after the 2 nd course. So, general result after 2 courses is $84.6 \%$ of wound healing.

Key words: diabetic foot syndrome, ischemia, treatment, Actovegin. 